\title{
German Participation in the Nuremberg Trials and Its Implications for Today
}

\author{
Christoph J. M. Safferling
}

The changing German perspective on the Nuremberg legacy over the last ten to fifteen years is best expressed by two quotations. Wilhelm G. Grewe (1911-2000), a German diplomat and scholar, wrote in 1985 (English translation 2000):

Hopes and expectations that were nourished in 1945 and the subsequent year and inspired by the models of the International Military Tribunals of Nuremberg and Tokyo, were illusory from the very beginning. These models could only impress zealots and starry-eyed idealists who were blind or dazzled by the realities of world politics. ${ }^{1}$

In contrast, Hans-Peter Kaul, also a German diplomat and the first German judge at the International Criminal Court (ICC), stated in an interview in 2003: "The Nuremberg Trials have initiated a process that is irreversible and at the end of which now stands the ICC." 2 There are not even twenty years between these comments by two Germans, and they could not be more opposite.

This article is divided into three sections: the first describes and explains this change in attitude and includes a few words on the recognition of the Nuremberg Trials at the time they took place and in the aftermath; the second is a discussion of the swing together soon after unification in 1990, with the sudden rebirth of international criminal law through the establishing of the ad hoc Tribunal for the Former Yugoslavia (ICTY) by the UN Security Council; and the third is a summary of the situation in which we are today, sixty years after the beginning of the trials against the major war criminals in Nuremberg.

1 Wilhelm G. Grewe, The Epochs of International Law (Berlin: DeGruyter, 2000), 667.

2 See www.auswaertiges-amt.de/www/de/ausgabearchiv?archivid=3357. See also Hans-Peter Kaul, "Der Beitrag Deutschlands zum Völkerstrafrecht," Völkerstrafrechtspolitik, eds. Christoph Safferling and Stefan Kirsch (Heidelberg: Springer, 2014), 51-84. 


\section{The Attitude towards the International Military Tribunal in Nuremberg during and for Forty Years after the Trials}

The German public did not follow the trials in Nuremberg closely for several reasons. First of all, people were primarily busy with organizing everyday life in the agonizing postwar environment, and second, the ability of the media to inform the public was limited due to the destruction in the country. ${ }^{3}$ Nevertheless, the Nuremberg Trials made the front page in newspapers and during the "Wochenschau" in cinemas. ${ }^{4}$ There was considerable anger amongst the population toward the Nazi leaders, who were considered responsible for the disastrous situation and the total collapse of civilization and therefore deserving of punishment. Around 80\% of the German population thought the Nuremberg Trials were fair and just; a mere $6 \%$ were critical, and some $9 \%$ thought the judgments were too harsh. ${ }^{5}$

German academia ignored the trials altogether at the time, because the general sentiment was that it was politically unwise to address them. With all necessary caution I must say that a considerable number of German law professors in the 1930s had known exactly what the Nazi Party wanted to hear and wrote accordingly in the hope of receiving swift promotion. This was particularly true in the so-called Kieler Schule, where in the early 1930s young law professors tried to "harmonize" Nazi ideology and jurisprudence in their teaching and writing at the University of Kiel. ${ }^{6}$ On the other hand, in 1946 and subsequent years, when the denazification process was under way, it was considered wise to do, without criticism, what was expected by the Allies.

At the beginning of the 1950s, German opinions about the Nuremberg Trials were quite diverse: about 30\% thought they were unfair, $40 \%$

3 Gerhard E. Gründler and Arnim von Manikowsky, Das Gericht der Sieger (Oldenburg/Hamburg: Gerhard Stalling Verlag, 1967), 10.

4 Because no one had a television set, special weekly newsreels were shown prior to the main film in theaters, a feature actually introduced by the Nazi public relations specialists during the Third Reich.

5 See Albin Eser, "Das Internationale Militärtribunal von Nürnberg aus deutscher Perspektive" ("The International Military Tribunal at Nuremberg from a German Perspective”), The Nuremberg Trials: International Criminal Law Since 1945, eds. Herbert R. Reginbogin, Christoph J. M. Safferling and Walter R. Hippel (Munich: Saur, 2006), 53-59.

6 See Jörn Eckert, "Was war die Kieler Schule?," Recht und Rechtslehre im Nationalsozialismus, ed. Franz Jürgen Säcker (Baden-Baden: Nomos, 1992), 37-70; and Bernd Rüthers, Entartetes Recht. Rechtslehre und Kronjuristen im Dritten Reich (Munich: C. H. Beck, 1988), 42-48. 
thought the judgments were too harsh, and 50\% said the Allies dealt with the German war criminals in the wrong way. ${ }^{7}$ After denazification slowed down, there was a tendency among Germans to avoid thinking about the past, particularly the Nazi regime. The Nuremberg Trials were seen as "victor's justice" ("Siegerjustiz"), organized by hypocritical victorious states that had been just as responsible for war crimes and crimes against peace as the Germans. ${ }^{8}$ At the same time, the Western Allies were pushing for a strong West Germany as a bulwark against Communism.?

This dramatic shift in attitude can be observed in several instances. Here I want to address several legal difficulties that were raised at the Nuremberg Trials and then focus on subsequent trials in West Germany and East Germany.

\section{Problems with the Nuremberg Trial}

The first difficulty was that the Anglo-American criminal procedure was foreign to the German lawyers, and they questioned its fairness. Also, while the defense lawyers ${ }^{10}$ could cope with the adversarial structure of the proceedings, against the prosecution-the U.S. team alone consisted of more than two hundred members - the defense teams seemed rather helpless. ${ }^{11}$ This latter criticism would have value in most criminal trials and describes a structural deficiency in general, and the discrepancy in means between the prosecution and the defense seems much larger in the Continental inquisitorial trial system than in the Anglo-American system. ${ }^{12}$ The former point, however - that the American procedure was foreign to the Ger-

7 See Eser, "Das Internationale Militärtribunal von Nürnberg," 57.

8 See Knut Ipsen, Völkerrecht (5th ed., Munich: C. H. Beck, 2004), $\$ 42$ MN 18.

9 See Norbert Frei, Vergangenheitspolitik. Die Anfänge der Bundesrepublik und die NSVergangenheit, (paperback 1st ed., Munich: C. H. Beck, 1999).

10 An overall analysis of the defence at Nuremberg is given by: Hubert Seliger, Politische Anwälte? Die Verteidiger der Nürnberger Prozesse (Baden-Baden: Nomos, 2014).

11 Klaus Kastner, Die Völker klagen an (Darmstadt: Primus, 2005); see also Benedikt Salleck, Strafverteidigung in den Nürnberger Prozessen (Berlin: Duncker \& Humblot, 2016).

12 For a structural comparative analysis of German and Anglo-American criminal procedures, see Christoph J. M. Safferling, Towards an International Criminal Procedure (Oxford: Oxford University Press, 2003), 54ff. 
man defense lawyers-cannot be maintained. ${ }^{13}$ The German defense lawyers acted as professionally as they could and learned to use, for example, the cross-examination feature-although one could say that it backfired dramatically when the defense called Rudolf Höss into the witness box. ${ }^{14}$

Another criticism of the Nuremberg Trials concerned the question of whether military leaders can be held responsible for political decisions. The defense, and in particular Professor Hermann Jahrreiß, who was the defense lawyer for Alfred Jodl, Commander in Chief of the German Wehrmacht, pleaded that a military leader follows orders but is not responsible for the political decision to go to war. ${ }^{15}$ The great military virtues of "Treue" and "Ehre" were extolled; loyalty and honor were demonstrated by fulfilling the oath every German soldier swore to the "Führer," after all. This discussion, old-fashioned as it may seem, is still vital in Germany and reached a late peak when in 1995 the Hamburg Institute for Social Science sponsored research by the well-known sociologist Jan Reemtsma into the crimes of the Wehrmacht. The resulting exhibition, "Dimensionen des Vernichtungskrieges 1941-1944," caused a real uproar among the general public. ${ }^{16}$ "Treue" and "Ehre" are all very well in principle, but the Nazi regime perverted this principle, and the SS and members of the Wehrmacht were willing to pursue an immoral war through immoral means in ruthless pursuit of "honor."

Perhaps the most important legal issue, however, was the violation of nullum crimen sine lege, the principle of non-retroactivity. The claim that the Nuremberg Trials violated this principle pertains in particular to the

13 Compare the treatise of the former Nuremberg defence counsel Otto Kranzbühler, Rückblick auf Nürnberg (Hamburg: Zeit Verlag, 1949), who offers a fairly balanced criticism of the Nuremberg Trials concerning the fairness of the proceedings.

14 See Whitney R. Harris, Murder by the Millions. Rudolf Hoess at Auschwitz (Jamestown, NY: The Robert H. Jackson Center, 2005).

15 Hermann Jahrreiß, "Der Bruch des zwischenstaatlichen Friedens und seine Strafbarkeit, Plädoyer vor dem Internationalen Militärgerichtshof zu Nürnberg,” Der Prozess gegen die Hauptkriegsverbrecher vor dem Internationalen Militärgerichtshof (Berlin: Rütten \& Loening, 1946), 53ff.; see also Otto Kranzbühler, "Die Kriegsverbrechergesetzgebung von Nürnberg als Rechtsproblem," Festschrift für Erich Kaufmann (Stuttgart: Kohlhammer, 1950), 219-226.

16 See Jan Philipp Reemtsma, Verbrechen der Wehrmacht. Dimensionen des Vernichtungskrieges 1941-1944. Ausstellungskatalog (2nd ed., Hamburg: Institut für Sozialforschung, 2002). 
crime against peace. ${ }^{17}$ The other crimes, such as war crimes and crimes against humanity, are in truth relatively unproblematical with regard to the principle of non-retroactivity. ${ }^{18}$ Informed people know this, but to the general public the entire prosecution was a violation of this principle. West Germany made the principle of non-retroactivity highly prominent place in its constitution; Art. 103 Abs. 2 GG reads: "An act may be punished only if it was defined by a law as a criminal offense before the act was committed." 19 This principle is essential for the rule of law ("Rechtsstaat"), but sometimes I have the impression that it is carried as a categorical icon and is misused to excuse highly immoral acts on merely formal grounds. ${ }^{20}$

The European Convention on Human Rights, an extremely successful instrument in promoting the rule of law and respect for human rights in Europe, incorporated the provision against retroactive prosecution in Article $7 \$ 2$. When it was drafted in 1950 , the memory of Nuremberg was still vivid, hence an exception was inserted for heinous atrocities which violate the conscience of humanity. The young West German democracy was cautious enough to implement a reservation to this exception, despite the fact that Gustav Radbruch, the pre-Nazi German Reichsminister for Justice, claimed that highly unjust laws cannot justify criminal acts. ${ }^{21}$ This reservation is a clear and unequivocal sign of mistrust against the proceedings at Nuremberg. ${ }^{22}$

Another flaw that was seen in the Nuremberg Trials was the fact that German victims were not made an issue. The cases that were brought before German courts after they were reopened later in 1945 and in the following years, could not make up for this lacuna. ${ }^{23}$ True, the Allies were primarily interested in prosecuting the major war criminals for the atrocities they committed on their territory and to punish them for the suffering

17 See, e.g., Hans-Heinrich Jescheck and Thomas Weigend, Strafrecht. Allgemeiner Teil (5th ed., Berlin: Duncker \& Humblot, 1996), 120.

18 See Gerhard Werle, Völkerstrafrecht (Tübingen: Mohr Siebeck, 2003), MN 25.

19 For a full English version of the German Grundgesetz, see http://www.iuscomp.org /gla/statutes/GG.htm.

20 See Werle, Völkerstrafrecht, MN 27-28. See especially the laconic comments by Winfried Hassemer and Walter Kargl, Nomos Kommentar StGB (2nd ed., BadenBaden: Nomos, 2005), $\$ 1$ MN 11.

21 Gustav Radbruch, "Gesetzliches Unrecht und übergesetzliches Recht," Süddeutsche Juristen Zeitung [1947], 634.

22 See Jens Meyer-Ladewig, EMRK-Handkommentar (Baden-Baden: Nomos, 2003), Art. 7 MN 11-12.

23 See Hans-Christian Jasch and Wolf Kaiser, Der Holocaust vor deutschen Gerichten. Amnestieren, Verdrängen, Bestrafen (Stuttgart: Reclam 2017), 35 et subs. 
among their people. The United States, on the other hand, was mostly interested in developing the crime of aggression and building a new world order on this, and the suffering of the German people before the war was ignored. Justice Jackson tried to establish a broad crime of conspiracy, which would have comprised this as well, but he did not succeed in the pre-Nuremberg diplomatic struggle to draft a statute for the IMT. It remains a pity that the persecution of Jews and other minorities living in Germany was not made a topic at Nuremberg. We still stand in shock at this terrible loss: through the Holocaust Germans eliminated the most talented, musical, artistic, literate part of its population.

\section{Prosecution of Nazis in West-Germany}

A look at the prosecution of Nazi criminals in West Germany after 1950 shows how astonishingly few prosecutions were brought forward and how very reluctantly courts convicted. ${ }^{24}$ Most of the proceedings that took place were carried by a strong sense of self-justification and understanding for the criminals. Whereas some of the most brutal SS-murderers were convicted and sentenced, those who had sat at their office desks and were responsible for planning and ordering the Holocaust were let off the hook. The German High Court of Justice achieved this by taking a strict subjective approach towards acting and abetting, and the outcome was as follows: the "Führer," together with his "gang," Himmler and Heydrich, was held criminally responsible for the death of millions of Jews, Gypsies, and others, while members of the administration, e.g., in the Reichssicherheitsamt, the office for home security, could only be prosecuted for abetting murder. Of course, abetting a crime is still a crime, but the sentence is far more lenient. Since the extradition of John Demjanjuk to Germany and his conviction by the Regional Court of Munich II, several cases against former guards at Auschwitz and other concentration camps have been

24 Statistical material can be found in Adalbert Rückerl, Die Strafverfolgung von NSVerbrechen 1945-1978 (Karlsruhe: C. F. Müller, 1979). See also Rebecca Wittmann, "The Normalization of Nazi Crime in Postwar West German Trials," The Nuremberg Trials: International Criminal Law Since 1945, eds. Herbert R. Reginbogin, Christoph J. M. Safferling and Walter R. Hippel (Munich: Saur, 2006), 209-215; Michael Bazyler, Holocaust, Genocide, and the Law. A Quest for Justice in a Post-Holocaust World (Oxford: OUP 2016), 109 et subs. 
prosecuted and are still beeing prosecuted in 2019. ${ }^{25}$ Most prominent amongst them was the conviction against Oskar Gröning, which was upheld by the German High Court of Justice. ${ }^{26}$

The same must be said of the prosecution of former Nazi judges. There is a criminal norm called "perversion of justice" by virtue of which judges can be held responsible for handing down arbitrary judgments. ${ }^{27}$ Here again the post-1950 High Court of Justice in Germany adopted the extreme subjective approach, and in the end, those judges who energetically flexed and bent the law in order to bring Nazi ideology and politics to reality, who sentenced to death thousands of innocent victims in blatant breach of any known legal methodology, were acquitted because they had acted in accordance with their convictions and believed they were fulfilling the law. ${ }^{28}$

Overall, German jurisprudence at the time seems to have been aiming at a "biological" solution to the problem of Nazi crimes: "Aussitzen"-basically sitting and waiting until the storm was over. ${ }^{29}$ However, criminal prosecution did have an impact on German society, especially the so-called Auschwitz Trial. ${ }^{30}$ The then General Attorney of the state of Hesse Fritz Baur, who was of Jewish origin and survived the Nazi regime in exile in Scandinavia, initiated a trial against twenty Auschwitz perpetrators, from guards to the commander, in 1963. This trial lasted for two years and re-

25 See Lawrence Douglas, The right wrong man. John Demjanjuk and the last great Nazi war crimes trial (Princeton: Princeton University Press, 2016).

26 See the collection of articles on the "last trials" against Nazi-criminals: Frank Lüttig and Jens Lehmann, Die letzten NS-Verfahren. Genugtuung für Opfer und Angehörige - Schwierigkeiten und Versäumnisse der Strafverfolgung (Baden-Baden: Nomos 2017).

27 "Section 339, Perversion of the Course of Justice: A judge, another public official, or an arbitrator, who in conducting or deciding a legal matter makes himself guilty of a perversion of the course of justice for the benefit, or to the detriment, of a party, shall be punished with imprisonment from one year to five years.” The full text of the German Criminal Code in English can be found at http://www.ius comp.org/gla/statutes/StGB.htm.

28 Most dramatic in this regard was the acquittal of the former Judge at the Volksgerichtshof (The Peoples Court) Hans-Joachim Rehse, Bundesgerichtshof, 30 April 1968 - 5 StR 670/67, Neue Juristische Wochenschrift (1968), 1339.

29 See Bernhard Schlink, Vergangenheitsschuld und gegenwärtiges Recht (Frankfurt a. M.: Suhrkamp, 2002), 14.

30 See Gerhard Werle and Thomas Wandres, Auschwitz vor Gericht. Völkermord und bundesdeutsche Strafjustiz (Munich: C. H. Beck, 1995); and Rebecca Wittmann, Beyond Justice: The Auschwitz Trial (Cambridge, MA: Harvard University Press, 2005). 
ceived considerable media attention - in fact it was primarily through this coverage that Germany was finally shown publicly what had really happened in Auschwitz. ${ }^{31}$ Commentator Professor Micha Brumlik concludes: "What West German society put aside, what politics couldn't do, what historiography was neither willing nor able to do-investigate the systematic mass murder committed by Germans-this was done by the Courts". ${ }^{32}$ Nevertheless, the overall outcome of the trial fitted into the general trend; Rebecca Wittman rightly observes: "The German public learned to chastise and denounce the sadistic 'excess perpetrator' of Auschwitz, and to forgive the order-followers." 33

In this context the question arises, how could the German people in general be so ready to forgive? Was there no moral sentiment of sorrow? Was there no collective grief? Germany had experienced total breakdown on May 8, 1945; however, due to political necessity West Germany had to be brought back to some strength, because the border between the Western and the Eastern Blocs divided the country. ${ }^{34}$ But where were the personnel that would occupy the posts of the new German jurisdiction? Any new German judge was supposed to be anti- or at least non-Nazi.

It is ironic and tragic at the same time, but German society was so completely infiltrated by National Socialism that it was simply impossible to find enough such people without waiting for an entire new generation. In the end many-too many-former obedient Nazi judges served as democratic judges, despite having actively supported or at least tolerated the Nazi ideology for twelve years. In some regions of Germany all of the pre-1945 judges kept their posts or were re-introduced into the judiciary. 35

31 The Auschwitz trial and Fritz Baur have drawn much attention in Germany in the last ten years. Three movies have been produced, internationally most prominent amongst them, the Film "Labyrinth of Lies" by Alexander Fehling in 2013; new biographies were written on Fritz Bauer, like Ronen Steinke: Fritz Bauer: oder Auschwitz vor Gericht (Munich: Piper 2013); and Irmtrud Wojak, Fritz Bauer 19031968. Eine Biographie (Munich: C. H. Beck, 2011).

32 Micha Brumlik, "Die Deutschen und der Auschwitz-Prozess," Frankfurter Rundschau, September 27, 2002.

33 Wittmann, Beyond Justice.

34 See Kim Priemel, The Betrayal. The Nuremberg Trials and German Divergence (Oxford: OUP, 2016), 368 et subs.

35 Hinrich Rüping, "Zwischen Recht und Politik: Die Ahndung von NS-Taten in beiden deutschen Staaten nach 1945" ("Between Law and Politics: The Prosecution of NS-Criminals in the Two German States after 1945"), The Nuremberg Trials: International Criminal Law Since 1945, eds. Herbert R. Reginbogin, Christoph J. M. Safferling and Walter R. Hippel (Munich: Saur, 2006), 199 -208; see also Wittmann, Beyond Justice. 
The question of lustration after the Nazi-regime was brought to the public attention in Germany starting in 2010 and has given rise to many commissions of experts established by federal agencies and ministries in order to research the history of the respective government institutions and their dealing with the Nazi-past. The process is still ongoing in 2019. ${ }^{36}$

And what could one expect from such a judiciary? Psychologically, the attempt to exonerate former Nazi criminals is quite understandable, because in this way the judges could exonerate themselves a little. The more understanding they showed in the trials against former Nazis, the better the light in which they themselves stood. ${ }^{37}$ It is hard to be called to judge as an outsider when in truth you are much more of an insider.

\section{Prosecution of Nazis in East Germany}

The Soviet occupied zone, which became the German Democratic Republic, had a different story. ${ }^{38}$ The "socialist" system that was established there claimed to be founded on anti-fascism and started out to prosecute former Nazi war criminals, but soon the shadow of a new suppressive systemcommunism-overlay any genuine attempt to come to terms with the past. Trials were utilized by the Party of Socialist Unity (SED) to get rid of persons who were unwilling to cooperate with it. The socialist state proclaimed that, unlike West Germany, it was not a successor to the fascist German Reich and thus was not responsible for atrocities committed by the Nazis and their followers. ${ }^{39}$

Before long the Socialist Party in East Germany had established a system which was just as repressive as the Nazis' secret police. And people lived

36 For a comprehensive summary, see: Christian Mentel and Niels Weise, Die Zentralen Deutschen Behörden und der Nationalsozialismus. Stand und Perspektiven der Forschung (Munich/Berlin: Institut für Zeitgeschichte, 2016). The present author was involved in such a commission of experts established by the Ministry of Justice, see: Manfred Görtemaker and Christoph Safferling, Die Akte Rosenburg. Das Bundesjustizministerium und die NS-Zeit (Munich: C. H. Beck, 2016).

37 See Schlink, Vergangenheitsschuld und gegenwärtiges Recht, $30 \mathrm{ff}$.

38 There has not been much research on this issue, but a compilation can be found in Rüping, "Zwischen Recht und Politik," 203ff.; but see now: Jasch and Kaiser, Der Holocaust vor deutschen Gerichten, 41 and 182.

39 A comprehensive comparison between West and East German dealing with the past, see: Frank Bösch and Andreas Wirsching, Hüter der Ordnung. Die Innenministerien in Bonn und Ost-Berlin nach dem Nationalsozialismus (Göttingen: Wallenstein, 2018), 13. 
with this for almost forty years. Then a miracle happened. In a totally peaceful revolution the East German population, usually perceived as rather phlegmatic, freed itself from the socialist burden by crying out: "We are the people!” On November 9, 1989, the Berlin Wall broke down just as former U.S. President Ronald Reagan had called on Soviet President Gorbachev to do. In an extremely emotional time Germany became a unified nation, and forty-five years after the end of World War II the 2+4 Treaty of 1990 was something like a peace treaty.

\section{The Attitude after German Unification}

Unification brought a change. Germany was forced to address the issue of Nazi crimes again because several German companies were sued for compensation of forced labor during the Third Reich. After a long, distressing legal and political struggle a foundation was established called "Remembrance, Responsibility, and Future," with an overall sum of five billion Euros to compensate for human rights atrocities committed by private enterprises which were part of the German war industry. It was much too late, of course, and a bit too much pressure was needed, and an acknowledgment of the actual legal claim was never achieved, but the payment of some money is a symbolic gesture expressing some moral responsibility. ${ }^{40}$

Unification brought back to general attention the problem of how to deal with systematic crimes, crimes ordered and supported by the state. In particular the so-called "Mauerschützen," i.e., the killings of trespassers by border guards, became test cases for the criminal justice system in Germany. ${ }^{41}$ Now the German judiciary proved ready and able to solve the legal issues it had been hindered from prosecuting in the preceding decades. Statutory limitations were not seen as a problem, because time had basically started again on Unity Day, October 3, 1990. Nor was the retroactivity principle seen as a problem, because any East German law that justified

40 See, e.g., Peer Zumbansen (ed.), NS-Forced Labor: Remembrance and Responsibility. Legal and Historical Observation (Baden-Baden: Nomos, 2002). See also Christoph J. M. Safferling, "Zwangsarbeiterentschädigung und Grundgesetz,” Kritische Justiz 34 (2001), 208.

41 The first "Mauerschützenfall": 39 BGHSt 1. An English translation of the first decision of the Bundesgerichtshof (High Court of Justice) can be found in: 100 ILR 364 (1995). See also the case against the former Party Council Members 48 BGHSt 77; 95 BVerfGE 96; and ECHR Streletz, Kessler, Krenz v. Germany, March 22, 2001, Reports 2001-II. 
killing a border-trespasser would be void in accordance with the Radbruch Formula. ${ }^{42}$

Was it again "victor's justice" when West Germany, on the victorious side of the Cold War, prosecuted East Germans? Further, did the West German judiciary try, as suggested by Bernhard Schlink, a constitutional lawyer, to compensate for earlier omissions regarding the prosecution of Nazi crimes?43

Another factor that influenced the development of the new German position on international criminal law was the horrible war in the Balkans in the first half of the 1990s, with incredible suffering among the civilian population and constant reports of genocide and crimes against humanity. The term "ethnic cleansing" was crafted to explain the atrocities in what used to be Yugoslavia. It came as something of a surprise, but the UN Security Council decided to establish the International Criminal Tribunal for the former Yugoslavia (ICTY), bowing to the idea of Nuremberg and setting up an international tribunal to prosecute crimes against so many innocent victims. And Germany was right in the middle of it all, because more than a few war criminals tried to escape from Yugoslav territory and find a safe haven there. The German Federal Prosecutor, however, reacted swiftly and charged these criminals with war crimes and genocide, and brought them before German courts on the basis of the principle of universality. ${ }^{44}$

One of the first to be arrested and indicted was Duško Tadić, who was later summoned by the ICTY and extradited to the UN Tribunal virtually on the eve of the day that he was supposed to stand trial before the High Court of Bavaria. It should be emphasized that in this case extradition was a complicated matter for Germany for constitutional reasons. The ICTY as

42 See Radbruch, "Gesetzliches Unrecht und übergesetzliches Recht”. See also Ralph Grunewald and Christoph J. M. Safferling, "Bundesgerichtshof in Strafsachen 2002/2003," Annual of German and European Law 2/3 (2004/2005), 378-398. The matter of "Perversion of Justice" according to Criminal Code $\$ 339$ was relevant again to prosecute SED-judges. Whereas the Federal Court of Justice abandoned the strictly subjective approach it applied to Nazi-judges, very few East German judges were convicted due to an overall restrictive interpretation of the norm. See Dirk Quasten, Die Judikatur des Bundesgerichtshofs zur Rechtsbeugung im NS-Staat und in der DDR (Berlin: Duncker \& Humblot, 2003).

43 Schlink, Vergangenheitsschuld und gegenwärtiges Recht, $39 \mathrm{ff}$.

44 See, e.g., Cristina Hoß and Russel Miller, "German Federal Constitutional Court and Bosnian War Crimes," German Yearbook for International Law 44 (2001), 576; and Christoph J. M. Safferling, "Prosecutor v Djajic", Neue Juristische Wochenschrift 51 (1998), 392, and American Journal of International Law 92 (1998), 528. 
an ad hoc tribunal was established ex post facto and the Grundgesetz, the German Constitution, prohibits such exceptional courts ("Ausnahmegerichte"). ${ }^{45}$ But the German government shelved constitutional doubts and passed legislation according to which Tadić could be transferred to The Hague.

The case of Tadic became in effect the test case for the ICTY. All the important questions regarding jurisdiction, retroactivity, and so forth were raised at this trial, and again something remarkable happened: in its first ever decision of October 2, 1995, ${ }^{46}$ the Appeals Chamber developed what Claus Kress, professor of German International Criminal Law at Cologne University and a great proponent of modern international criminal law in Germany, calls the "second generation of international crimes". ${ }^{47}$ With this term he tries to grasp the shift away from an international criminal law that is applicable only to international armed conflicts to international criminal law with a wider scope.

Since this decision the concepts of crimes against humanity and war crimes are also applicable in part to purely internal conflicts. ${ }^{48}$ In its decision the Appeals Chamber referred to the Nuremberg judgments over and over again in order to buttress its arguments in favor of a wider view of customary law for war crimes in internal conflicts. At the Conference "Judging Nuremberg" on July 19, 2005, Claus Kress said: "Therefore a government that insists that the principle of non-retroactivity needs to be applied in full force to crucial cases in public international law, too, would have had reasons to criticize the Tadic jurisprudence." 49 At the same conference the German Undersecretary of Justice, Hansjörg Geiger, emphasized in his address the importance of the Tadić trial and the positive role Germany played in it. In the meantime, the German government under

45 Article 101 of the Grundgesetz reads as follows: “(1) Extraordinary courts shall not be allowed. No one may be removed from the jurisdiction of his lawful judge. (2) Courts for particular fields of law may be established only by a law."

46 ICTY Prosecutor v. Duško Tadić, Case No. IT-94-1-AR72, October 2, 1995.

47 Claus Kress, "Germany and International Criminal Law: Continuity or Change?," The Nuremberg Trials: International Criminal Law Since 1945, eds. Herbert R. Reginbogin, Christoph J. M. Safferling and Walter R. Hippel (Munich: Saur, 2006), 235-241.

48 See Werle, Völkerstrafrecht, MN 806-809.

49 Kress, "Germany and International Criminal Law". See also Werle Völkerstrafrecht, MN 28. 
then Secretary of State Joschka Fischer somehow silently revoked the reservation made to Article $7 \$ 2$ ECHR on Oct $5,2001 .{ }^{50}$

\section{Closing Remarks}

Germany now shows a different attitude toward international criminal trials than before, and in discussions about a permanent ICC, the German government is playing a pro-active role. At the Rome conference for the establishment of the ICC, the German delegation was led by Hans-Peter Kaul, with Whitney Harris and Ben Ferencz as counsellors, both former prosecutors at Nuremberg - the prosecutors and the formerly accused nation working together to continue what was started at the Nuremberg Trials in order to prevent future crimes. What more could we wish for to keep the legacy of Justice Jackson alive?

The new government which came into power in Germany in 1998 under Chancellor Gerhard Schroeder and Secretary of State Joschka Fischer supported the struggle for international criminal justice, and Germany ratified the Rome Statute and passed a Code of International Crimes (Völkerstrafgesetzbuch [VStGB]), which can be seen as the most modern codification of substantive international criminal law and serves as a blueprint for many countries desiring to amend their national laws to fit the Rome Statute's requirement of complementarity. ${ }^{51}$ Hans-Peter Kaul was elected the first German judge at the ICC; later he was elected president of the pretrial chamber and as such administered the beginning of the first case of genocide in the situation of Dafur/Sudan at the ICC.

There is still a lot to be done. The German government is continuing to work on the ICC issue, and the Foreign Office includes a Working Commission on International Criminal Law consisting of practitioners-there

50 See Der 6. Bericht der Bundesregierung über ibre Menschenrechtspolitik in den auswärtigen Angelegenheiten und in anderen Politikbereichen (Human Rights Report), 2000/02, 36 [www.bmj.bund.de/media/archive/267.pdf]. The reservation was revoked about six months after the decision by the European Court on Human Rights (ECHR) in a case against the former SED party members Streletz, Kessler, Krenz v. Germany, March 22, 2001, Reports 2001-II, where the Court held that Article $7 \$ 2$ ECHR was inapplicable as the crimes committed by the accused were punishable even according to former GDR law, so that the principle of-non retroactivity was not violated.

51 See Christoph J. M. Safferling, "German Public Law Legislation - 2001/2002: Das Völkerstrafgesetzbuch," Annual of German and European Law 1 (2003), 365; an English text of the VStGB is reproduced ibid at 667. 
are many German lawyers working at the International Tribunals, with the international prosecutor, and at the ICC-and academics in international criminal law. ${ }^{52}$ Professor Albin Eser, the former director of the prestigious Max-Planck-Institute for Criminal Law and ad litem judge at the ICTY, admitted in Nuremberg in 2005 that in his work at the Tribunal he encounters the Nuremberg Trials on an everyday basis. ${ }^{53}$ A German judge using Nuremberg as a precedent - things have truly changed.

The sentiments of the German people concerning international justice can be summarized in the following way: Germans are totally certain and unified in their efforts towards achieving a properly working ICC with as many members and supporters as possible, because they have learned one thing: for state-supported atrocities, national courts are not well chosen to prosecute. There must be a complementary ICC ready to take over prosecution if the national system fails. This constitutes a warranted limitation to state sovereignty. ${ }^{54}$

There is one more thing that I have come to appreciate more and more during this very special year of remembrance: Nuremberg was not only the birth of international criminal law, it was also the beginning of democracy in Germany. The principles of human rights and the rule of law as the answer to cruelty provide a good basis for society. My idea of democracy is shaped by Justice Jackson and by what he expressed in his opening speech in courtroom 600 in the Palace of Justice in Nuremberg about the necessity to give every human being a fair and independent hearing: "For these defendants, however, we have set up an International Tribunal and have undertaken the burden of participating in a complicated effort to give them fair and dispassionate hearings. That is the best-known protection to any man with a defense worthy of being heard."

52 Since the drafting of this paper things have developed in different ways. Whereas the German judiciary has taken up old Nazi-cases and convicted several SSGuards at Concentrations Camps (see above note XX), the armed conflict in Syria forces German prosecutors to investigate international crimes committed during that conflict by either German nationals or refugees.

53 Eser, "Das Internationale Militärtribunal von Nürnberg".

54 See also Bruce Broomhall, International Justice \& the International Criminal Court (Oxford: Oxford University Press, 2003), 20-21; and Christoph J. M. Safferling, "Can Criminal Law be the Answer to Massive Human Rights Violations?," German Law Journal 5 (2004), 1469, 1472. 